\title{
Design and optimization of a renewable hybrid system applied in airports
}

\section{Diseño y optimización de un sistema hibrido renovable aplicado en aeropuertos}

\author{
ABSALON-SOTO, Dorian Hugo †* \& GÓMEZ-GONZÁLEZ, Francisco Javier \\ Tecnológico Nacional de México, campus Veracruz \\ ID $1^{\text {st }}$ Author: Dorian Hugo, Absalon-Soto / ORC ID: 0000-0002-7935-6354, CVU CONACYT ID: 957279 \\ ID $1^{\text {st }}$ Coauthor: Francisco Javier, Gómez-Gónzalez / ORC ID: 0000-0001-7798-9601, Research ID Thomson: I-6550-2018, \\ CVU CONACYT ID: 831120
}

\begin{abstract}
This paper shows the development of a methodology for the optimization of a hybrid generation system applied in airports. First, the renewable resources available in the area are characterized, the commercial demand profile of electricity consumption is obtained, and the system configuration is proposed. Later, we proceed to the optimization, where the simulation tool HOMER is used for this purpose. The software can determine the net present cost (NPC) and the cost of energy (COE) of different combinations. With the information obtained, it is possible to find the optimal combination of components to satisfy the load demand at the most affordable cost. The proposed methodology is applied to the General Heriberto Jara Corona International Airport, with the purpose of reducing the costs of electric energy consumption and greenhouse gas (GHG) emissions, considering the aeronautical physical easements established by the International Civil Aviation Organization (ICAO). Finally, the profitability of the optimized renewable system is evaluated, thus contributing to sustainable development of the airport.
\end{abstract}

\section{Airport, Optimization, Renewable hybrid system}

\begin{abstract}
Resumen
El presente artículo muestra el desarrollo de una metodología para la optimización de un sistema de generación hibrido aplicado en aeropuertos. En principio se caracterizan los recursos renovables disponibles en la zona, se obtiene el perfil de demanda comercial de consumo eléctrico y se propone la configuración del sistema. Posteriormente, se procede a la optimización, en donde se emplea la herramienta de simulación HOMER para este propósito. El software tiene la capacidad de determinar el costo neto presente (NPC) y el costo de energía (COE) de distintas combinaciones. Con la información obtenida, es posible encontrar la combinación óptima de componentes para satisfacer la demanda de carga al costo más asequible. La metodología propuesta es aplicada al Aeropuerto Internacional General Heriberto Jara Corona, con la finalidad de reducir los costos de consumo de energía eléctrica y las emisiones de gases de efecto invernadero (GEI), considerando las servidumbres físicas aeronáuticas establecidas por la Organización de Aviación Civil Internacional OACI. Finalmente se evalúa la rentabilidad de sistema renovable optimizado, contribuyendo así, al desarrollo sustentable del aeropuerto.
\end{abstract}

Aeropuerto, Optimización, Sistema híbrido Renovable

Citation: ABSALON-SOTO, Dorian Hugo \& GÓMEZ-GONZÁLEZ, Francisco Javier. Design and optimization of a renewable hybrid system applied in airports. Journal of Technological Operations. 2021. 5-15: 10-17

\footnotetext{
* Author Correspondence (e-mail: dorian.absalon@hotmail.com).

$\dagger$ Researcher contributing as first author.
} 


\section{Introduction}

Electric power is one of the most indispensable services for humanity. Currently, more than $73 \%$ of the world's demand is supplied by burning fossil fuels such as oil, coal and natural gas (IEA, 2020). However, the rapid consumption of fossil energy has not only led to a global fossil energy crisis but also aggravated environmental problems (Lian et al., 2019) due to high GHG emissions such as $\mathrm{CO}_{2}$, causing global warming and climate change.

At the commercial level, in the transportation sector, one of the main contributors to GHG emissions are airports, as most airports rely on conventional power plants to meet their electrical energy needs (Sreenath et al., 2020). Carbon emissions from airports come mainly from aircraft engines and/or electricity consumption.

In this regard, the aviation industry as a whole and airports are seeking to limit their carbon footprint. One feasible solution is to replace conventional electric power consumption with clean energy sources (Sukumaran \& Sudhakar, 2017).

As a background, Cochin International Airport Limited (CIAL) was the first airport in the world to operate entirely on solar energy. On August 18, 2015, CIAL was operating entirely on renewable energy by installing 46,150 solar panels spread over 45 acres (Paramashivaiah et al., 2018). Other representative examples of airports that have adopted renewable energy systems at their facilities are in Newcastle, Auckland, Dublin, and the City of London (Baek et al., 2016).

On the other hand, surfaces within the airport are normally open, wide, uninhabited areas, with no obvious turbulence caused by natural obstacles or surrounding tall buildings (Cuadra et al., 2019).

Based on the above, this article proposes the optimal sizing of a hybrid renewable system, applied to the General Heriberto Jara Corona International Airport, and the technical economic analysis of different generation systems, to reduce the costs of electricity consumption and $\mathrm{CO}_{2}$ emissions.
First, the article presents the general definition of a hybrid renewable system. Subsequently, the methodology applied, the general information of the Veracruz International Airport, the characterization of the renewable resources available in the area, the energy demand profile, and the optimization of the proposed renewable system with the support of the simulation tool for renewable hybrid systems HOMER are presented. Finally, the results are analyzed, and conclusions are drawn.

\section{Hybrid renewable system}

Replacing fossil fuels for energy production with renewable resources is essential to limit the impact of climate change. However, the unpredictable nature of renewable energy sources such as sun and wind complicates their integration into the energy system (Alberizzi et al., 2020). This problem can be solved by introducing a hybrid system based on different renewable energy technologies (HRES).

A great advantage of this system is based on the combination of one or more renewable energy sources. In these combinations, the optimal energy generation from one source can complement the deficiency of another (González et al., 2015). In addition, its operation, can be autonomous or connected to the power grid. Figure 1 shows a basic configuration for a HRES.

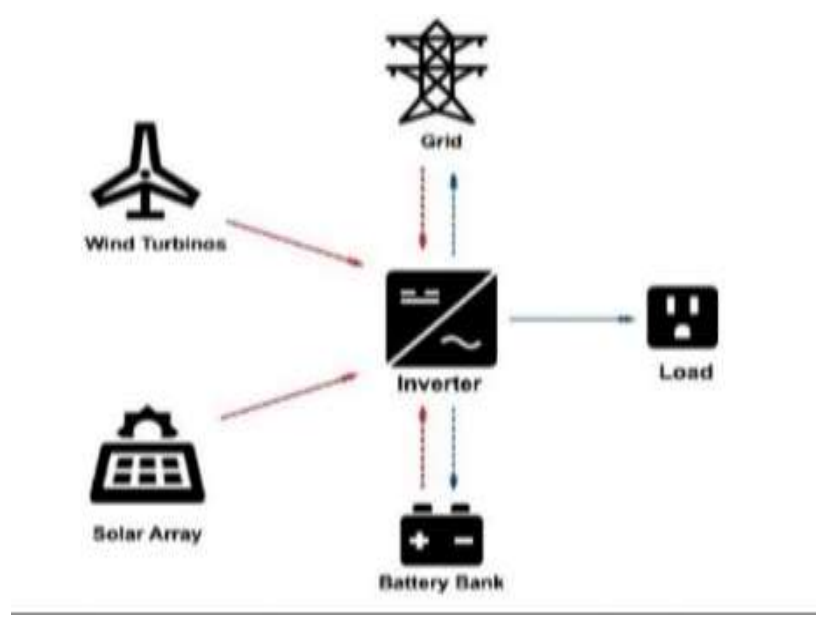

Figure 1 Hybrid renewable system (Donado et al., 2019).

\section{Methodology}

There are a limited number of articles in the literature related to the implementation of HRES at airports. Most of the studies focus on rural areas connected to or isolated from the electrical grid. 
This article proposes the methodology schematically represented in Figure 2, which includes, among other aspects, the technical constraints to be considered when installing renewable energy technologies at an airport.

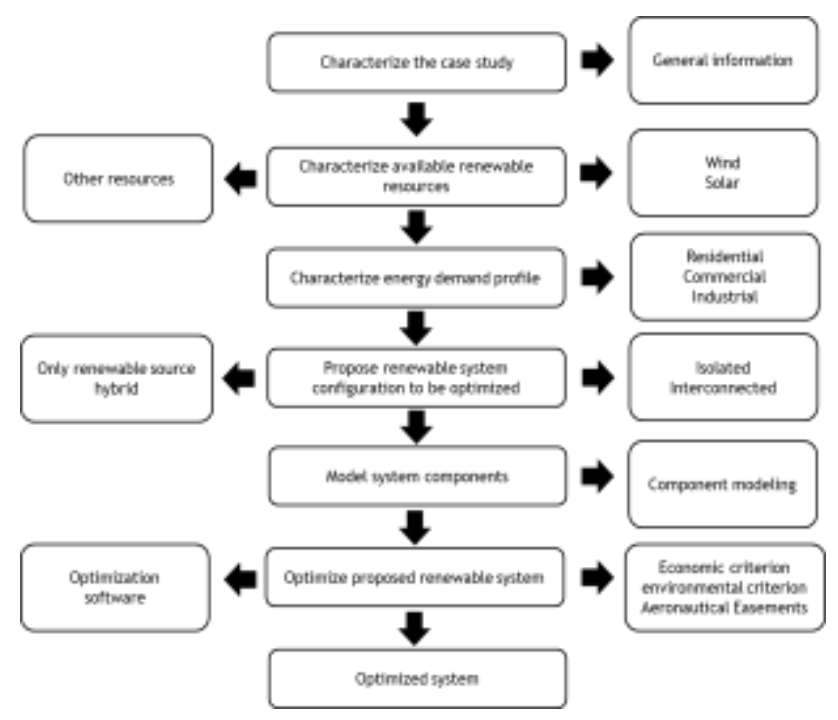

Figure 2 Structure of the proposed methodology

\section{Characterization of the case study}

The Heriberto Jara Corona International Airport is located within the municipality of Veracruz, $10 \mathrm{~km}$ from the coast of the Gulf of Mexico, in the Las Bajadas property, at latitude $19^{\circ} 8^{\prime} 30.35$ "N' and longitude $96^{\circ} 11^{\prime} 1.24$ "W, at an altitude of 27.43 meters above sea level. Figure 3 shows the geographic location of the Veracruz airport within the Mexican Republic.

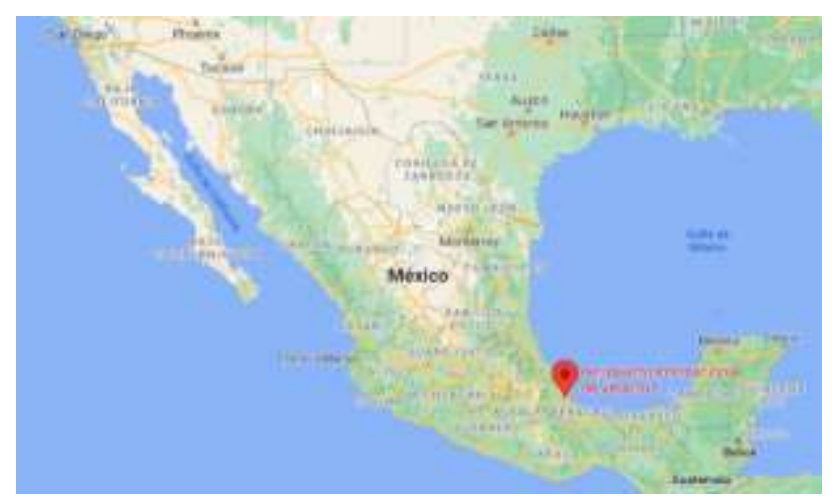

Figure 3 Geographic location of Heriberto Jara Corona Airport, in the Mexican Republic (Google, 2021)

Regarding passenger mobility, the port services management company ASUR, in its 2019 annual sustainability report, explains how in recent years, due to the increase in the number of passengers per year, the operating environment at the Veracruz airport has been changing, generating increased energy demand and thus raising billing costs (Cerrejón S.A., 2019).
The Veracruz airport has a vast uninhabited open space, free of turbulence caused by natural obstacles or surrounding tall buildings and has a good existing connection to the medium voltage power grid. Figure 4 shows the satellite view of the Heriberto Jara Corona airport.

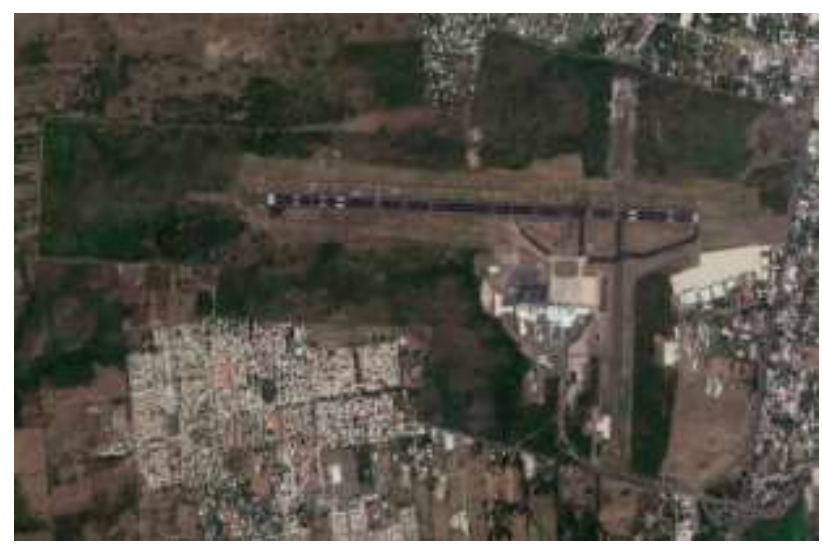

Figure 4 Satellite view of Heriberto Jara Corona Airport (Google, 2021)

Regarding the average climate in the area, during the year, the temperature generally varies from $18^{\circ} \mathrm{C}$ to $33^{\circ} \mathrm{C}$ and rarely falls below $14{ }^{\circ} \mathrm{C}$ or rises above $36{ }^{\circ} \mathrm{C}$. The season with the highest amount of wind during the year lasts 8.3 months, from September 16 to May 25, with average speeds of more than 12.2 kilometers per hour (Weatherspark, 2021).

\section{Characterization of renewable resources}

For this case, the average annual wind speed between 2016 and 2020 is obtained as shown in Graph 1, where a similar behavior can be observed in the annual wind speed curve for the five years characterized. The data were collected by the anemometer shown in Figure 5 and located within the runway area of the airport itself.

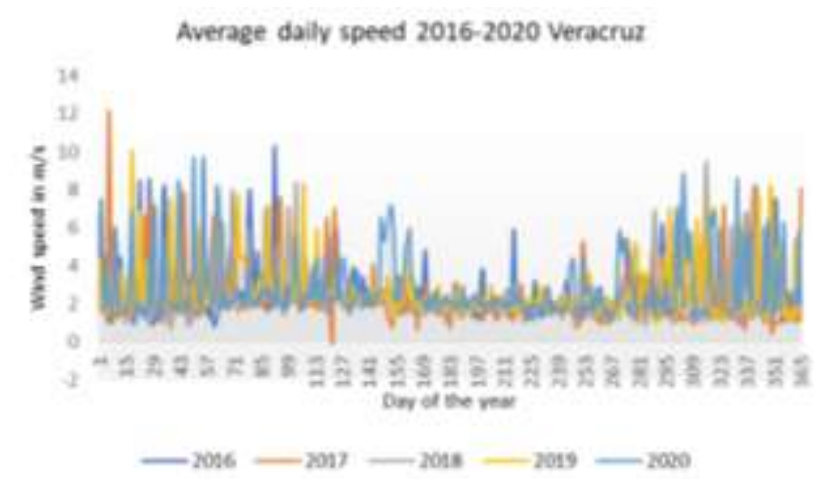

Graph 1 Average annual velocity from 2016 to 2020 


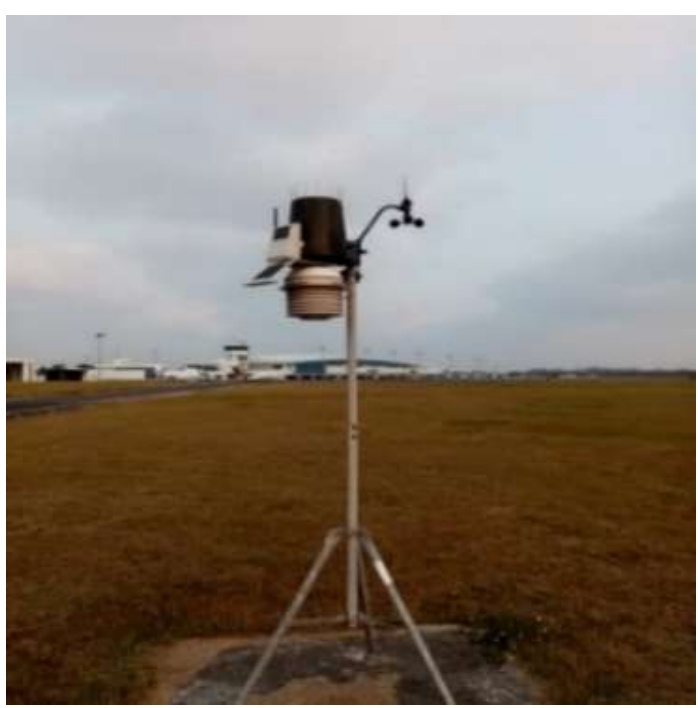

Figure 5 Anemometer installed inside the runway area

As for solar radiation and temperature in the area, these are obtained through the HOMER hybrid system simulation software (HOMER, 2020), which uses NASA's POWER Data Access Viewer interface for this purpose. Graph 2 shows the monthly average solar radiation incidence during one year in the area. The month of May has the highest solar radiation with 5.46 $\mathrm{kWh} / \mathrm{m}^{2} /$ day and a brightness index of 0.502 .

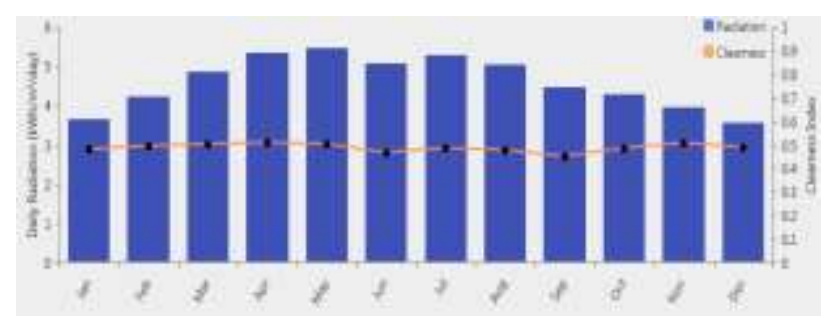

Graph 2 Average solar radiation-day in a year

The highest daily average temperature is $28^{\circ} \mathrm{C}$, corresponding to the month of May, as shown in Graph 3.

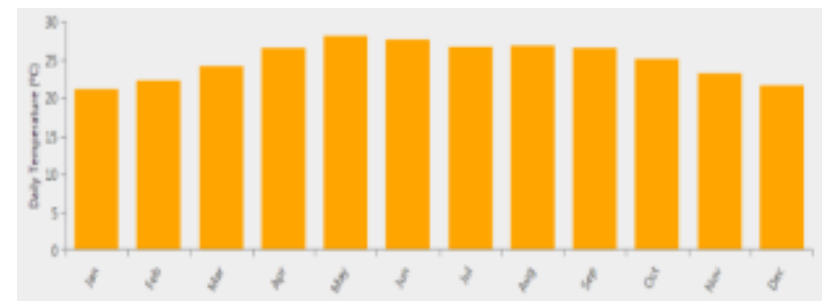

Graph 3 Average daily temperature in a year

\section{Load profile}

Graph 4 shows the airport's electricity consumption during 2019 and 2020, according to electricity billing receipts. It can be seen how the current COVID 19 pandemic affected electricity demand in 2020, due to a decrease in passenger mobility.

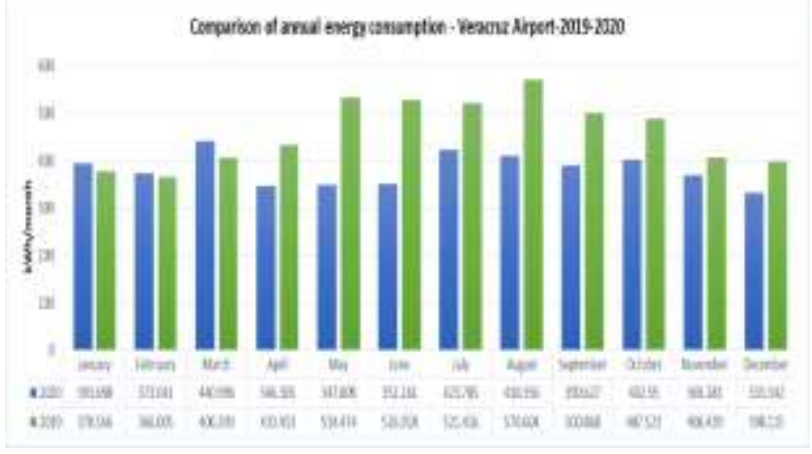

Graph 4 Comparison of annual energy consumption in 2019 and 2020

The average consumption corresponds to $15,153.1 \mathrm{kWh} /$ day, with an average load of $631.41 \mathrm{~kW}$ and peak demand of up to $1,746.9$ $\mathrm{kW}$. Graph 5 shows the commercial demand profile of the Veracruz Airport.

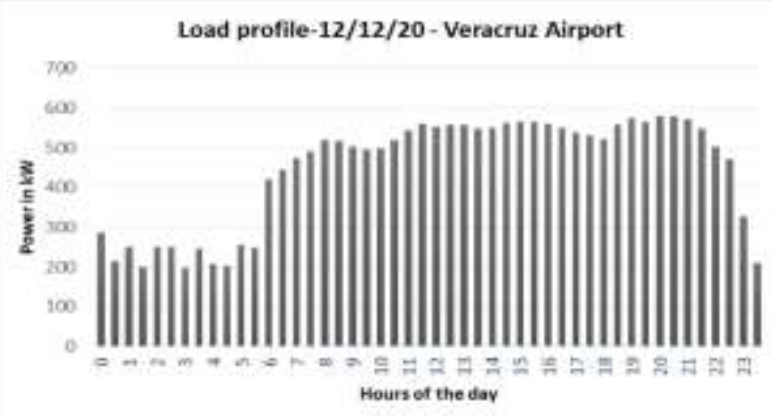

Graph 5 Daily load profile of the Veracruz international airport.

\section{Modeling of components.}

The total energy production of the hybrid system can be calculated from the power generation of the solar panels and the wind turbine. The mathematical expression of the energy produced by the hybrid system is as follows:

$P_{T}=N_{W} * P_{W}+N_{S} * P_{S}$

Where, $P_{T}$ is the total power generated by the system, $P_{W}$ is the power obtained from the wind turbine, $P_{S}$ is the power obtained from the solar panels, $N_{S}$ is the number of solar panels and $N_{W}$ is the number of wind turbines (Khalil et al., 2020). For the PV module, the power output depends on different factors (materials, temperature, and incident irradiance) and can be expressed as follows:

$P_{P V}=P_{S T C} \frac{G(\beta, \alpha)}{G_{S T C}}\left\lfloor 1+\gamma\left(T_{C}-T_{S T C}\right)\right\rfloor$ 
Where $P_{S T C}$, is the nominal power of the PV module (W) at standard test conditions (STC), $G(\beta, \alpha)$ is the incident irradiance in the plane of the panels $\left(\mathrm{W} / \mathrm{m}^{2}\right), G_{S T C}$ is the incident irradiance at standard test conditions $\left(\mathrm{W} / \mathrm{m}^{2}\right), \gamma$ is the temperature coefficient, $T_{S T C}$ is the temperature at standard test conditions $\left({ }^{\circ} \mathrm{C}\right)$ y $T_{C}$ is the cell temperature $\left({ }^{\circ} \mathrm{C}\right)$, which can be expressed as:

$$
T_{C}=\left(T_{a}-273\right)+\frac{G(\beta, \alpha)}{800}(N O C T-20)
$$

Where $T_{a}$ is the ambient temperature $\left({ }^{\circ} \mathrm{K}\right)$, and NOCT is the nominal cell operating temperature $\left({ }^{\circ} \mathrm{C}\right)$. The values of $P_{S T C}, \gamma, \mathrm{y} N O C T$ are provided by the PV panel manufacturer. On the other hand, the power of wind turbines can be estimated as follows:

$$
P_{W T}=\frac{1}{2} \cdot \rho \cdot A \cdot C_{P} \cdot v^{3}(z)
$$

Where $P_{W T}$ is the output power of the wind turbine $(\mathrm{W}), \rho$ is the air density $\left(\mathrm{kg} / \mathrm{m}^{3}\right)$, $v_{(z)}$ is the wind speed at the wind turbine hub height $(\mathrm{m} / \mathrm{s}), A$ is the rotor swept area $\left(\mathrm{m}^{2}\right)$, and $C_{P}$ is the power coefficient of the wind turbine. The values of $A$ y $C_{P}$ are provided by the turbine manufacturer (Arcos-Aviles et al., 2017).

\section{System configuration}

The proposed architecture consists of the following units: supply grid, AWS HC $1.5 \mathrm{~kW}$ horizontal three-bladed wind turbine, $340 \mathrm{~W}$ Canadian solar photovoltaic panel and inverters with a capacity of $1 \mathrm{~kW}$. The system architecture is shown schematically in Figure 6.

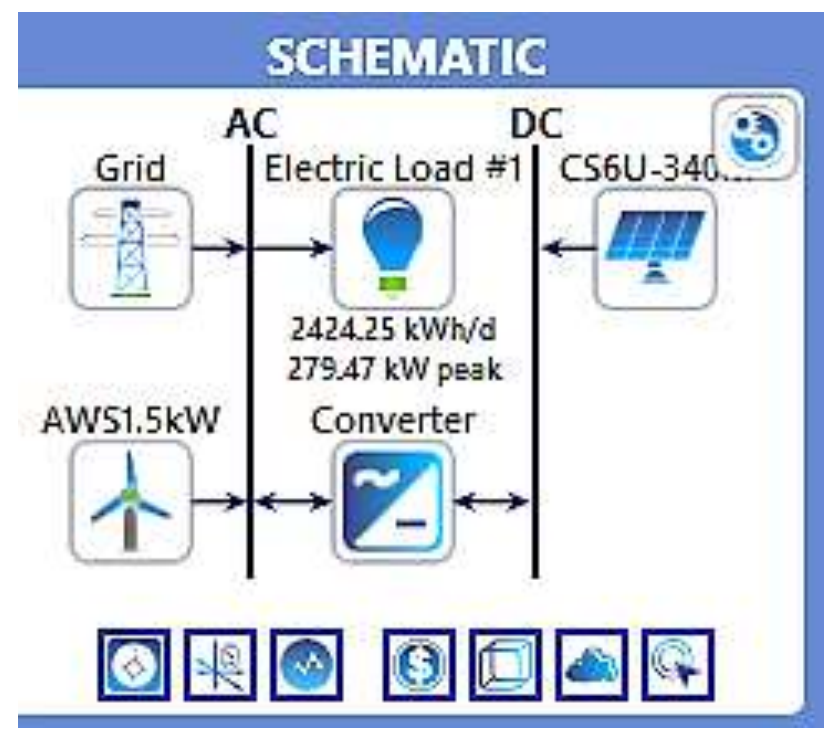

Figure 6 Architecture of the proposed system.

\section{System optimization}

Once the estimation of the renewable resources available in the locality, the energy consumption profile and the proposed system architecture were available, the optimization software for hybrid renewable systems HOMER (Hybrid Optimization Model for Electric Renewables), developed by the National Renewable Energy Laboratory of the United States (NREL), was applied. For the optimization of the system, two scenarios were analyzed, in which HOMER was provided with data on the renewable resource, the demand and the costs of investment, operation, maintenance, replacement and the GDMTH (Gran Demanda Media Tensión Horaria) tariff applicable to the airport.

\section{a. Scenario 1}

In this scenario, the simulation was applied without capacity restriction of the generation units, where two combinations were obtained that meet the electricity needs for the airport, which are ordered from lowest to highest Net Present Cost (NPC) and Cost of Energy (COE). The optimal combination is identified in Table 1.

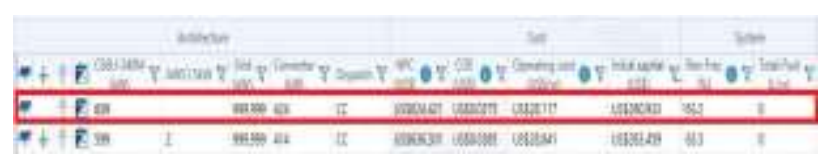

Table 1 Optimal combination, without generation capacity restriction.

\section{Combination 1}

This is the optimal combination according to HOMER. The installed capacity of the photovoltaic panels is $609 \mathrm{~kW}$ and of the inverters is $424 \mathrm{~kW}$, without the presence of wind turbines.

\section{Combination 2}

In this configuration, all system components are considered. It includes two wind turbines, an installed capacity of $599 \mathrm{~kW}$ of photovoltaic panels and an inverter array of $414 \mathrm{~kW}$. 


\section{b. Scenario 2}

In this scenario, the simulation was carried out with a restriction in generation capacity, applying a search space where the generation units do not exceed $500 \mathrm{~kW}$ or $0.5 \mathrm{MW}$. As in scenario 1 , the two combinations were analyzed for the case study. The optimal combination is identified in Table 2.

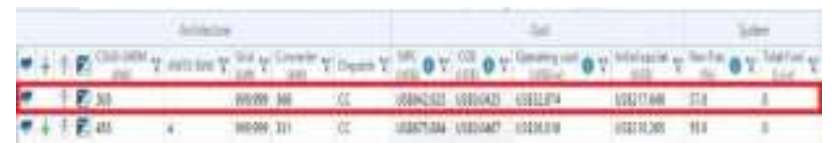

Table 2 Optimal combination, with generation capacity restriction.

\section{Combination 1}

In this combination, the installed capacity of the $\mathrm{PV}$ panels is $503 \mathrm{~kW}$ and that of the inverters is $368 \mathrm{~kW}$.

\section{Combination 2}

All system components are considered in this configuration; it includes four wind turbines, an installed capacity of $453 \mathrm{~kW}$ of photovoltaic panels and an inverter array of $331 \mathrm{~kW}$.

As a summary, Table 3 shows the results found in each of the scenarios and combinations.

\begin{tabular}{|l|l|l|l|}
\hline \multicolumn{2}{|c}{ Scenario 1 } & \multicolumn{1}{c|}{ Scenario 2 } \\
\hline \multirow{4}{*}{$\begin{array}{l}\text { Combination } \\
\text { N }\end{array}$} & Net present & $\$ 624,421.00$ & $\$ 642,625.00$ \\
\cline { 2 - 4 } & Cost of & $\$ 0.0375$ & $\$ 0.0425$ \\
\cline { 2 - 4 } & Initial & $\$ 260,933$ & $\$ 217,648$ \\
\cline { 2 - 4 } & Renewable & $63.2 \%$ & $57.8 \%$ \\
\cline { 2 - 4 } \begin{tabular}{l} 
Combination \\
\cline { 2 - 4 }
\end{tabular} & $\mathrm{CO}_{2}$ & 299,102 & 312,053 \\
\cline { 2 - 4 } & Net present & $\$ 636,301.00$ & $\$ 675,884.00$ \\
\cline { 2 - 4 } & Cost of & $\$ 0.0385$ & $\$ 0.0467$ \\
\cline { 2 - 4 } & Initial & $\$ 263,459$ & $\$ 210,265$ \\
\cline { 2 - 4 } & Renewable & $63.3 \%$ & $55.9 \%$ \\
\cline { 2 - 4 } & $\mathrm{CO}_{2}$ & 296,571 & 312,154 \\
\hline
\end{tabular}

Table 3 Summary of scenario and combination results.

\section{Analysis of results}

In the first scenario without installation capacity restriction, for combination 1 , a net present cost of $\$ 624,421.00$ USD and a renewable fraction of $63.2 \%$ is obtained. HOMER proposes this configuration as the optimal one, which shows a balance between the cost per unit of energy and the penetration of renewable energy.
In the second combination without limitation of installed capacity of equipment, the net present cost rises due to the inclusion of wind turbines and the percentage of renewable fraction increases slightly to $63.3 \%$.

In the second scenario, considering the installed capacity limitation, for combination 1, the net present cost is $\$ 642,625.00$ USD and the energy cost is $\$ 0.0425$ USD. Compared to the first combination of the first scenario, both costs are higher.

In the last combination, the net present cost is the highest of the 4 combinations. In this case, the renewable fraction is $55.9 \%$, the lowest of the combinations.

It is pertinent to mention that the second scenario with installed capacity restriction complies with the Mexican energy regulatory framework established by the Electricity Industry Law (LIE), therefore, it is considered as the optimal and suggested combination for the Veracruz International Airport. Table 4 shows a cost summary for the suggested system architecture.

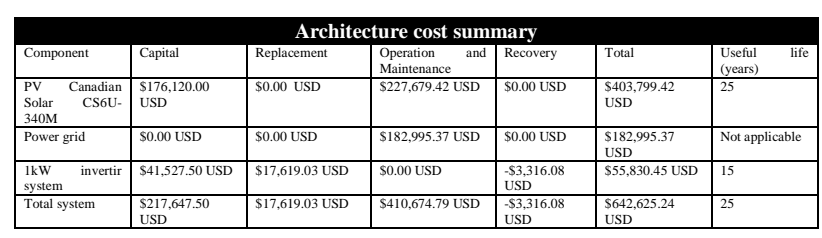

Table 4 Summary of cost for the proposed architecture.

\section{Conclusions}

According to the results, the average annual wind potential in the Veracruz International Airport is considered limited, so the installation of wind turbines is not recommended due to its low level of generation.

The design and optimization of the gridconnected hybrid system presents combination 1 of scenario 1 as the optimal option. It requires 1,792 photovoltaic panels of $340 \mathrm{~W}$ and inverter capacity of $424 \mathrm{~kW}$. This represents a net present cost of $\$ 12,500,783.54$ Mexican pesos, a renewable fraction of $63.2 \%$ and a payback time of 7.83 years. 
However, this optimization does not comply with the regulatory framework in Mexico where the maximum installation capacity in distribution systems is limited to 500 $\mathrm{kW}$ or $0.5 \mathrm{MW}$. Based on the above, combination 1 of scenario 2 is selected, where the system architecture consists of 1,480 photovoltaic panels of $340 \mathrm{~W}$ and an installed inverter capacity of $368 \mathrm{~kW}$, with a lifetime cost of $\$ 12,865,223.97$ Mexican pesos, a renewable fraction of $57.8 \%$ and a reduced payback time of 7.66 years.

Finally, the installation of the proposed hybrid system requires an approximate area of $2,940 \mathrm{~m}^{2}$ equivalent to only $1.20 \%$ of the total area available at the airport. The aeronautical physical easements established by the International Civil Aviation Organization, which determine different safety distances relative to the runway, are considered.

The dissemination of this article will serve as a guide in the implementation of renewable hybrid systems in national and international airports, thus promoting sustainable development in the aviation industry.

\section{References}

Alberizzi, J. C., Frigola, J. M., Rossi, M., \& Renzi, M. (2020). Optimal sizing of a Hybrid Renewable Energy System: Importance of data selection with highly variable renewable energy sources. Energy Conversion and Management, 223(March), 113303. https://doi.org/10.1016/j.enconman.2020.11330 3

Arcos-Aviles, D., Pascual, J., Guinjoan, F., Marroyo, L., Sanchis, P., \& Marietta, M. P. (2017). Low complexity energy management strategy for grid profile smoothing of a residential grid-connected microgrid using generation and demand forecasting. Applied Energy, 205(May), 69-84. https://doi.org/10.1016/j.apenergy.2017.07.123

Baek, S., Kim, H., \& Chang, H. J. (2016). Optimal hybrid renewable airport power system: Empirical study on Incheon International Airport, South Korea. Sustainability (Switzerland), $\quad 8(6)$. https://doi.org/10.3390/su8060562
Cerrejón S.A. (2019). Informe anual de sostenibilidad ambiental 2019. 1-128. www.cerrejon.com

Cuadra, L., Ocampo-Estrella, I., Alexandre, E., \& Salcedo-Sanz, S. (2019). A study on the impact of easements in the deployment of wind farms near airport facilities. Renewable Energy, 135 , 566-588. https://doi.org/10.1016/j.renene.2018.12.038

Donado, K., Navarro, L., Quintero, M. C. G., \& Pardo, M. (2019). HYRES: A multi-objective optimization tool for proper configuration of renewable hybrid energy systems. Energies, 13(1). https://doi.org/10.3390/en13010026

González, A., Riba, J. R., Rius, A., \& Puig, R. (2015). Optimal sizing of a hybrid gridconnected photovoltaic and wind power system. Applied Energy, 154, 752-762. https://doi.org/10.1016/j.apenergy.2015.04.105 Google. (2021). Google Earth Pro (7.3.2.5491).

HOMER. (2020). HOMER Energy. https://www.homerenergy.com/

IEA. (2020). World Energy Balances. World Energy Balances, IEA, Edición 2020. https://www.iea.org/reports/world-energybalances-overview/world

Khalil, L., Liaquat Bhatti, K., Arslan Iqbal Awan, M., Riaz, M., Khalil, K., \& Alwaz, N. (2020). Optimization and designing of hybrid power system using HOMER pro. Materials Today: $\quad$ Proceedings, $\quad x x x x, \quad 4-9$. https://doi.org/10.1016/j.matpr.2020.06.054

Lian, J., Zhang, Y., Ma, C., Yang, Y., \& Chaima, E. (2019). A review on recent sizing methodologies of hybrid renewable energy systems. Energy Conversion and Management, 199(April),

112027. https://doi.org/10.1016/j.enconman.2019.11202 7

Paramashivaiah, P., Chakraborthy, S., \& Shashidhar, R. (2018). Illuminating an Airport with Sustainable Energy: Case of Cochin International Airport. OIDA International Journal of Sustainable Development. 
Sreenath, S., Sudhakar, K., Yusop, A. F., Solomin, E., \& Kirpichnikova, I. M. (2020). Solar PV energy system in Malaysian airport: Glare analysis, general design and performance assessment. Energy Reports, 6, 698-712. https://doi.org/10.1016/j.egyr.2020.03.015

Sukumaran, S., \& Sudhakar, K. (2017). Fully solar powered airport: A case study of Cochin International airport. Journal of Air Transport Management, 62 , 176-188. https://doi.org/10.1016/j.jairtraman.2017.04.00 4

Weatherspark. (2021). El clima promedio. Es.Weatherspark.Com. https://es.weatherspark.com/y/145974/Climapromedio-en-Aeropuerto-InternacionalGeneral-Heriberto-Jara-México-durante-todoel-año 